\title{
Metal bioavailability assessment in 'mussel-watch' programmes by automated image analysis of autometallographical black silver deposits (BSD) in digestive cell lysosomes
}

\author{
Manu Soto*, Ionan Marigómez
}

Biologia Zelularra Atala, Zoologi eta Animali Zelulen Dinamika Saila, Zientzi Fakultatea, Euskal Herriko Unibertsitatea, 644 P.K., E-48080 Bilbo, Basque Country, Spain

\begin{abstract}
The extent of autometallographical black silver deposits (BSD) was quantified by automated image analysis in digestive lysosomes of the digestive gland of mussels collected from 2 estuaries of the coast of Biscay for 1 yr. Additionally, metal composition of digestive lysosomes was characterised by $X$-ray microprobe analysis. Zn levels were the most variable among the metals analysed by $\mathrm{AAS}(\mathrm{Cd}, \mathrm{Cr}, \mathrm{Cu}, \mathrm{Ni}, \mathrm{Zn}, \mathrm{Pb}, \mathrm{Fe})$. A logarithmic regression model explained the changes in volume density (VD) of BSD by changes in the $\mathrm{Zn} /$ shell-wt index recorded in mussels from different sites of the coast. Similar regression models were obtained between the VD of BSD and metal/shell-wt indices resulting from pooling the 7 metals ( $\mu$ mol metal $\mathrm{g}^{-1}$ dry shell weight). In conclusion, metal bioavailability can be estimated by analysing the VD of BSD in the digestive lysosomes of sentinel mussels. This index may allow workers to discard chemical analysis of biological samples when low traces of metals are present in the tissues, since the method proposed herein provides a quick and costeffective alternative to routine chemical analyses in biomonitoring programmes. Only when values of VD of BSD reach the plateau of the function would a more accurate chemical analysis be required. This approach does not require special facilities or specialised technicians and would reduce the time and cost of routine metal determination in water pollution monitoring programmes.
\end{abstract}

KEY WORDS: Field validation - Autometallography - Digestive lysosomes · Automated image analysis AAS - Metal content - Correlation analysis - X-ray microanalysis - Metal pollution monitoring

\section{INTRODUCTION}

A variety of technical approaches have been applied in pollution biomonitoring programmes in order to estimate the bioavailable fraction of metals. Many of these techniques deal with the chemical analysis of marine molluscs by AAS (atomic absorption spectrophotometry) and provide data on the metal concentration in sentinel molluscs. Previous works have reported on many variables (biotic and abiotic) affecting the estimation of metal bioavailability in terms of metal concentrations in soft tissues of sentinel mussels (Phillips 1976, 1980, Lobel \& Marshall 1988, Widdows \& Donkin 1992, Rainbow 1993). However, some authors

\footnotetext{
•E-mail: zopsolom@lg.ehu.es
}

have criticised the reliability of these estimates because a great number of natural variables other than changes in metal bioavailability may affect metal concentrations in the soft body of molluscs (Fischer 1984 1988, Marigómez \& Ireland 1990, Marigómez et al. 1990, Theede \& Soria 1990, Soto et al. 1995, 1996c). The application of an index (metal/shell-weight index. i.e. metal content in soft tissues/dry shell weight of mussels) to exclude the effect of those variables and to reflect more accurately the bioavailable fraction of metals in the environment represents an attractive alternative (Fischer 1984, 1986, 1988, Marigómez \& Ireland 1989, Marigómez et al. 1990, Regoli \& Orlando 1993, Soto et al. 1995). However, this index (calculated for each metal: $\mu \mathrm{g}$ metal in soft dry tissue weight/g dry shell weight; and/or computed as normalised data for all the metals: $\mu$ mol total metal in soft dry tissue 
weight/g dry shell weight) still is affected by certain variables to some extent.

On the other hand, some histochemical analyses may allow an accurate determination of the metal levels in biological samples and may reduce the influence of undesired natural variations (Marigómez et al. 1995, Soto \& Marigómez 1995, Soto et al. 1996a, b). Autometallography is a method based on the autoinduced silver amplification of metal ions in biological sections. Tissue sections are covered by a photographic emulsion and rinsed in a photographic developer, and afterwards, black silver deposits (BSD) reveal the presence of metal ions in the tissue $(\mathrm{Zn}, \mathrm{Cd}, \mathrm{Cr}, \mathrm{Ni}, \mathrm{Cu}, \mathrm{Au}, \mathrm{Ag}$, $\mathrm{Pb}, \mathrm{Fe}, \mathrm{Hg}$, etc., except Ca; Danscher 1981, 1984, 1991, Hacker et al. 1988, Danscher \& Montagnese 1994, Soto et al. in press b).

To our knowledge, few studies applying autometallography have been carried out to demonstrate metallic presence in cell compartments of molluscs (Hemelraad \& Herwig 1988, Herwig et al. 1989, Soto et al. $1996 \mathrm{a}, \mathrm{b}$ ). However, semi-quantitative estimates of the extent of BSD in digestive cell lysosomes and basal lamina of molluscs experimentally exposed to metals are significantly correlated with metal concentration in the digestive gland measured by conventional methods using AAS (Soto \& Marigómez in press, Soto et al. in press a). Therefore, the semi-quantitative evaluation of $\mathrm{BSD}$ in digestive cell lysosomes of molluscs is proposed as an index for routine screening of metal pollution. Soto \& Marigomez (in press) concluded that BSD extent is a low cost index that accurately reflects the total concentration of metals (measured by AAS) in the digestive gland of mussels, and concomitantly, the fraction of bioavailable metals for molluscs in seawater However, field validation studies are required before this index can be applied in 'mussel-watch' biomonitoring programmes. For this purpose, the automated quantification of BSD by means of automated image analysis is also needed to avoid subjectivity in semi-quantification procedures.

In the present study, the extent of BSD in digestive lysosomes was quantified by automated image analysis in a field study and correlated with the metal content of sentinel mussels. The aim of this work was to validate the use of the index as an alternative analysis to complement chemical analyses for the assessment of the bioavailable fraction of metals in 'mussel-watch' biomonitoring programmes.

\section{MATERIALS AND METHODS}

Experimental design. The Abra Estuary (Fig. 1; Bay of Biscay, $43^{\circ} 19^{\prime}$ to $43^{\circ} 23^{\prime} \mathrm{N}, 03^{\circ} 05^{\prime}$ to $03^{\circ} 00^{\prime} \mathrm{W}$ ) was used as a natural experimental basin; it has wellknown differences (spatial and seasonal) in the levels of metallic pollutants (Azkona et al. 1984, Swindlehurst \& Johnston 1991, Soto et al. 1995). In accordance with previous work dealing with estimation of metal bioavailability by means of atomic absorption spectrophotometry (Soto et al. 1995) 3 sampling sites were chosen: Zierbena (showing a high bioavailability for iron) on the western side, Arrigunaga (with intermediate levels of metal bioavailability) on the eastern side, and Plentzia $\left(43^{\circ} 26^{\prime} \mathrm{N}, 2^{\circ} 55^{\prime} \mathrm{W}\right)$, located in a small unpolluted estuary with low levels of metals. Additionally, mussels known to show high bioavailability for $\mathrm{Zn}$ (conc. $\pm \mathrm{SD}=501.5 \pm 194.2 \mu \mathrm{g} \mathrm{Zn} \mathrm{g}{ }^{-1}$ dry weight; Soto 1995) were also collected in Meñakoz $\left(43^{\circ} 24^{\prime} \mathrm{N}\right.$, $2^{\circ} 93^{\prime} \mathrm{W}$ ) near the Abra Estuary in winter 1989.
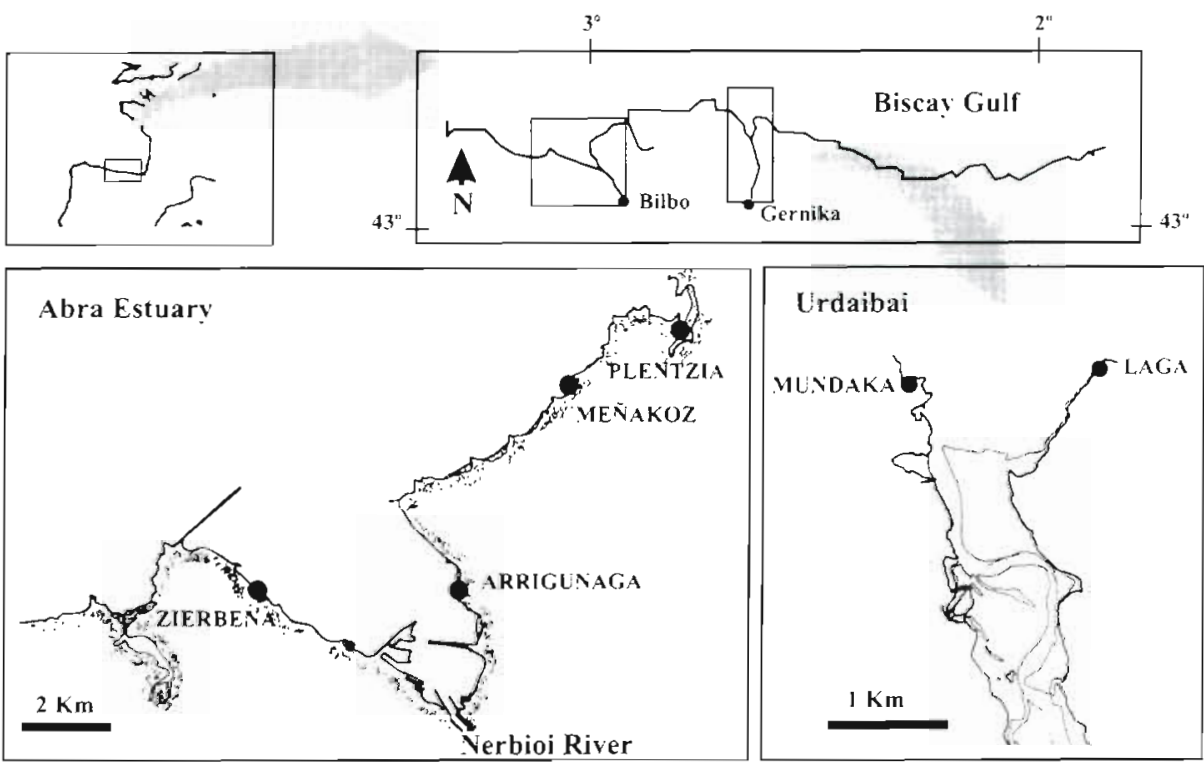

Fig. 1. Location of the Abra and Urdaibai estuaries on the Biscayan coast 
The second estuary selected for this study was the Estuary of Urdaibai (Fig. 1; Biscayan coast; $43^{\circ} 20^{\prime} \mathrm{N}$ $3^{\circ} \mathrm{W}$ ), which was declared a 'Natural Reserve of the Biosphere' (UNESCO) in 1984. Metal bioavailabilities previously reported in this estuary did not change with season and there were no differences between sites. Only discrete events of increased metal bioavailability have been recorded (Soto et al, 1996c). Two sampling sites were chosen: Mundaka (on the western side) and Laga (outside of the estuary to the east).

Mussels Mytilus galloprovincialis Lmk. from the minimum low tide level and measuring 3.5 to $4.5 \mathrm{~cm}$ in maximum shell length (Marigómez et al. 1992) were collected in winter (January and February 1992), summer (July and August 1992) and autumn (September and October 1992) in the Abra and Urdaibai estuaries.

Autometallography (Danscher 1984). Ten mussels per site and month were dissected in situ, rinsed in Bouin's fixative (Martoja \& Martoja-Pierson 1970) and immediately transferred to the laboratory in portable iceboxes. Tissue samples were fixed at $4^{\circ} \mathrm{C}$ for $36 \mathrm{~h}$, dehydrated in alcohols, cleared in methylbenzoate, rinsed in benzene and embedded in paraffin. Histological sections $(7 \mu \mathrm{m})$ were cut in a Leitz 1512 microtome.

Paraffin sections were dewaxed in xylene, hydrated in ethanol-water mixtures and left at $40^{\circ} \mathrm{C}$ until completely dry. Afterwards, tissue sections were covered with a uniform thin layer of photographic emulsion (Ilford Nuclear Emulsion L4) under safety light conditions (Danscher 1984, Soto et al. in press b). After drying in completely dark conditions (30 min) sections were rinsed in developer bath (hydroquinone and sodium hydroxide, 1:5; Ultrafin Tetenal SF) for $15 \mathrm{~min}$, rinsed in stop bath ( $1 \%$ acetic acid) for 1 min and rinsed in fixative bath (sodium thiosulphate, 1:9; Agefix) for $10 \mathrm{~min}$. Emulsion was checked before every use by covering a slide without tissue to test for uniformity silver grains, BSD indicated the presence of metal ions (Danscher 1984, Soto et al. in press b). Sections were mounted in Kaiser gelatine and sealed with nail varnish.

Quantification of BSD by automated image analysis. The extent of BSD in digestive lysosomes of digestive gland of mussels was quantified by automated image analysis (Cajaraville et al. 1991) as volume density (VD) of lysosomal BSD in relation to digestive tubule volume. Light microscopical images were acquired by a system consisting of a black \& white CCD TV camera, a high resolution TV colour screen, a Leitz microscope, a PC-AT computer (40 Mbyte RAM), a PIP 1024 (Matrox) boardset and software developed by Filosoft (Spain). An objective lens of $100 \times$ magnification was used. Binary images separating BSD from digestive cell cytoplasm were obtained by a segmentation procedure, in which the binary threshold was manually adjusted in the first measurement of a given section to correct for slight differences in staining intensity between different sections. Further measurements used the same threshold. Five measurements were made in each section of 10 mussels per experimental group in order to calculate the volume density. The computer uses the stereoscopic images to generate the VD according to Lowe et al. (1981): VD = $V_{\mathrm{B}} / V_{\mathrm{C}}$ ), where $\mathrm{VD}=$ volume density, $V_{\mathrm{B}}=$ volume of black silver deposits $\left(\mu \mathrm{m}^{3}\right)$, and $V_{C}=$ volume of digestive cell cytoplasm $\left(\mu \mathrm{m}^{3}\right)$.

Chemical analysis. Fifty mussels per site and month were immediately transferred to the laboratory in plastic bottles within portable iceboxes. Then, mussels were distributed in plastic tanks in a thermostatically controlled $\left(13\right.$ to $15^{\circ} \mathrm{C}$ ) continuous-water-flow system, with active-charcoal and glass-wool filtered natural seawater, for $48 \mathrm{~h}$ in the absence of food in order to eliminate the gut contents prior to metal analysis. After dissection, soft tissues were rinsed in distilled water and dried at $120^{\circ} \mathrm{C}$ for $48 \mathrm{~h}$ until constant weight was reached. Fifty mussels per sampling site were grouped in pools of 5 mussels each (giving 10 replicates per sample), digested in concentrated nitric acid, diluted with $0.1 \mathrm{M}$ nitric acid and analysed by atomic absorption spectrophotometry (Perkin Elmer 2280 spectrophotometer) with simultaneous background correction and a sensitivity of $0.3 \mathrm{mg} \mathrm{l^{-1 }}$. Merck standard solutions were diluted in $0.1 \mathrm{M}$ nitric acid for calibration. Seven metals were analysed: cadmium (Cd), chromium (Cr), lead $(\mathrm{Pb})$, nickel $(\mathrm{Ni})$, copper $(\mathrm{Cu})$, zinc $(\mathrm{Zn})$ and iron $(\mathrm{Fe})$. The original data on measured concentrations of these 7 metals are in Soto et al. $(1995,1996 \mathrm{c})$. Bioavailabilities for each metal were calculated as metal/shellweight indices ( $\mu \mathrm{g}$ metal in soft tissues $\mathrm{g}^{-1}$ dry shell weight). Metal/shell-weight indices were then transformed into $\mu \mathrm{mol}$ total metal $\mathrm{g}^{-1}$ dry shell weight in order to standardise metal data (see Table 1).

$\mathrm{X}$-ray microprobe analysis. The elemental composition of digestive cell lysosomes was determined by $X$-ray microanalysis. Portions of the digestive gland of mussels from Zierbena, Arrigunaga, Plentzia, Mundaka and Galea were excised for electron probe X-ray microanalysis in winter 1992. Samples were fixed in Karnovsky's fixative (in 0.2 M cacodylate buffer, $\mathrm{pH}=7.2$ ) for $2 \mathrm{~h}$ at $4^{\circ} \mathrm{C}$ (Glauert 1986), washed in the same buffer, dehydrated in alcohols and embedded in Araldite resin. Digestive glands of mussels from Meñakoz (winter 1989) were processed following the K-pyroantimoniate method to retain diffusible ions such as $\mathrm{Zn}$ and $\mathrm{Ca}$ when processing the samples (Chandler 1977, Pearse 1980, Morgan 1985, Compère et al. 1993, Hayat 1993). Indeed, what is visualised is the presence of $\mathrm{Sb}$ in the cellular sites where those diffusible ions were. Postfixation with osmium tetroxide and post-staining with 
lead citrate and uranyl were not performed to avoid Os and $U$ masking of metal peaks in the X-ray spectra (Chandler 1977). Thick sections were obtained by cutting in a Reichert Jung ultramicrotome, collected on formvar/carbon-coated titanium grids (200 mesh) and overcoated with carbon. Analyses were carried out in a Hitachi-H-800-HT (Scanning System H8010) microscope fitted with a Kevex (Quantum) energy dispersive spectrometer (EDS) with Quantex (Kevex) software.

Statistics. Variability in VD of BSD was tested using 2-way analyses of variance (see Table 2) to detect the effects of sampling period (SP), sampling site (SS) and the interaction between them (SP $\times$ SS). Significant differences were stablished at the $p<0.05$ level using Duncan's test for multiple range comparison between pairs of means. A regression analysis was made between VD of BSD in digestive lysosomes of mussels from all the sampling stations at different seasons and the metal/shell-weight indices ( $\mu \mathrm{mol} \mathrm{g}^{-1}$ dry shell weight) found in the whole mussel. All statistical analyses were performed with the SPSS/PC+ statistical package (SPSS, Microsoft) using a 486 PC computer.

\section{RESULTS}

\section{Quantification of autometallographical BSD by automated image analysis}

BSD in cell lysosomes of mussels collected from Abra and Urdaibai are shown in Fig. 2. VD of BSD are shown in Fig. 3. The variables sampling site (S) and sampling month ( $\mathrm{T}$ ) significantly affected the VD of BSD of mussels from Abra (Table 1). In this estuary (Fig. 3A), the highest VD was found in digestive lysosomes of mussels from Zierbena in contrast with the very low values recorded in mussels from Plentzia In the Urdaibai estuary (Fig. 3B), however, only the inter-

Table 1. Mytulus galloprovincialis. Values of total metal/shell-weight indices ( $\mu \mathrm{mol}$ total metal $\mathrm{g}^{-1}$ dry shell weight), with VD values $\left(\mu \mathrm{m}^{3} / \mu^{3}{ }^{3}\right)$ in parentheses. nd: no data avallable

\begin{tabular}{|c|c|c|c|}
\hline & Winter 1992 & Summer 1992 & Autumn 1992 \\
\hline \multicolumn{4}{|l|}{ Abra } \\
\hline Zierbena' & $27.4661(0.0642)$ & $5.8703(0.0265)$ & $3.8613(0.0683)$ \\
\hline Arrigunaga ${ }^{b}$ & $4.0464(0.0194)$ & $5.0703(0.0254)$ & $2.8257(0.0278)$ \\
\hline Menakoz & $7.7847(0.2659)^{\mathrm{d}}$ & nd & nd \\
\hline Plentzia ${ }^{b}$ & $3.5875(0.0300)$ & $1.9313(0.0035)$ & $1.0090(0.0159)$ \\
\hline \multicolumn{4}{|l|}{ Urdaibai } \\
\hline Mundaka ${ }^{b}$ & $9.2835(0.0512)$ & $6.4527(0.0521)$ & $0.9017(0.0012)$ \\
\hline $\operatorname{Laga}^{\mathrm{b}}$ & $4.1049(0.0198)$ & $3.2853(0.0118)$ & nd \\
\hline \multicolumn{4}{|c|}{$\begin{array}{l}{ }^{\text {a }} \text { Collected in winter } 1989 \\
{ }^{b} \text { Metals quantified by AAS: Cu, Cd, Zn, Cr, Ni, Pb, Fe. } \\
\text { cMetals quantified by AAS: Cu, Cd, Zn }\end{array}$} \\
\hline
\end{tabular}

Table 2. Summary of 2-way ANOVAs analyzing the effect of sampling site (SS), sampling period (SP) and their interaction $(\mathrm{SP} \times \mathrm{SS})$ on the VD of BSD in digestive cell lysosomes of mussels Mytilus galloprovincialis from Abra and from Urdaibal. $F$ : F-ratio, probability of $F: " p<0.05, \cdots p<0.001$. Degrees of freedom (df): for $A b r a, d f(S S)=2, d f(S P)=2, d f(S P \times S S)=$ 4, $\operatorname{df}($ residual $)=58 ;$ for Urdaibai, $\operatorname{df}(\mathrm{SS})=1, \operatorname{df}(\mathrm{SP})=2$, $\mathrm{df}(\mathrm{SP} \times \mathrm{SS})=2, \mathrm{df}($ residual $)=31$

\begin{tabular}{|lllc|}
\hline & $F(S S)$ & $F(S P)$ & $F(S P \times S S)$ \\
\hline Abra & $7.972^{\circ}$ & $3.198^{\circ}$ & 1.268 \\
Urdaibai & 0.312 & 1.814 & $9.052{ }^{\circ}$ \\
\hline
\end{tabular}

action between $\mathrm{S}$ and $\mathrm{T}(\mathrm{S} \times \mathrm{T})$ affected significantly (Table 2) the VD of BSD in digestive lysosomes. Mussels from Mundaka showed higher VD than mussels from Laga in digestive lysosomes all through the sampling seasons with the exception of winter where VD of BSD was severely reduced in both sites (Fig. 3B).

When all data of VD of BSD in digestive lysosomes of mussels collected in winter (Abra, 1992; Urdaibai, 1992) were taken into account and compared with the data available on Meñakoz, a heavily polluted site. significant differences between groups were found by means of a 1 -way ANOVA (Fig. 4A $i p<0.001$ ). The VD of the extent of BSD in digestive lysosomes of mussels from Menakoz was significantly higher than in any other group (Duncan's t-test, $\mathrm{p}<0.05$ ).

\section{Quantitative chemical analyses (AAS)}

The $\mathrm{Zn} /$ shell-weight index ( $\mu$ mol $\mathrm{Zn} \mathrm{g}^{-1}$ dry shell weight) for mussels collected in winter is shown in Fig. 4B. The highest $\mathrm{Zn} /$ shell-weight index was found in mussels from Meñakoz (1989), whilst mussels from the other sampling sites exhibited intermediate (Mundaka, Zierbena) to low (Laga, Plentzia, Arrigunaga) values.

Data on total metal/shell-weight index ( $\mu \mathrm{mol}$ total metals $\mathrm{g}^{-1}$ dry shell weight) for the sites located in the Abra and in Urdaibai estuaries in the 3 sampling seasons are shown in Table 1. These data suggest that Zierbena exhibited the highest metal bioavailability within the Abra Estuary whilst Mundaka showed the highest metal bioavailability in Urdaibai.

\section{Qualitative X-ray microprobe analysis}

$X$-ray microprobe analysis indicated the presence of $\mathrm{Zn}$ in lysosomes of the digestive cells of mussels collected from Meñakoz in Winter 1989 (Fig. 5C). The presence of Os in this 


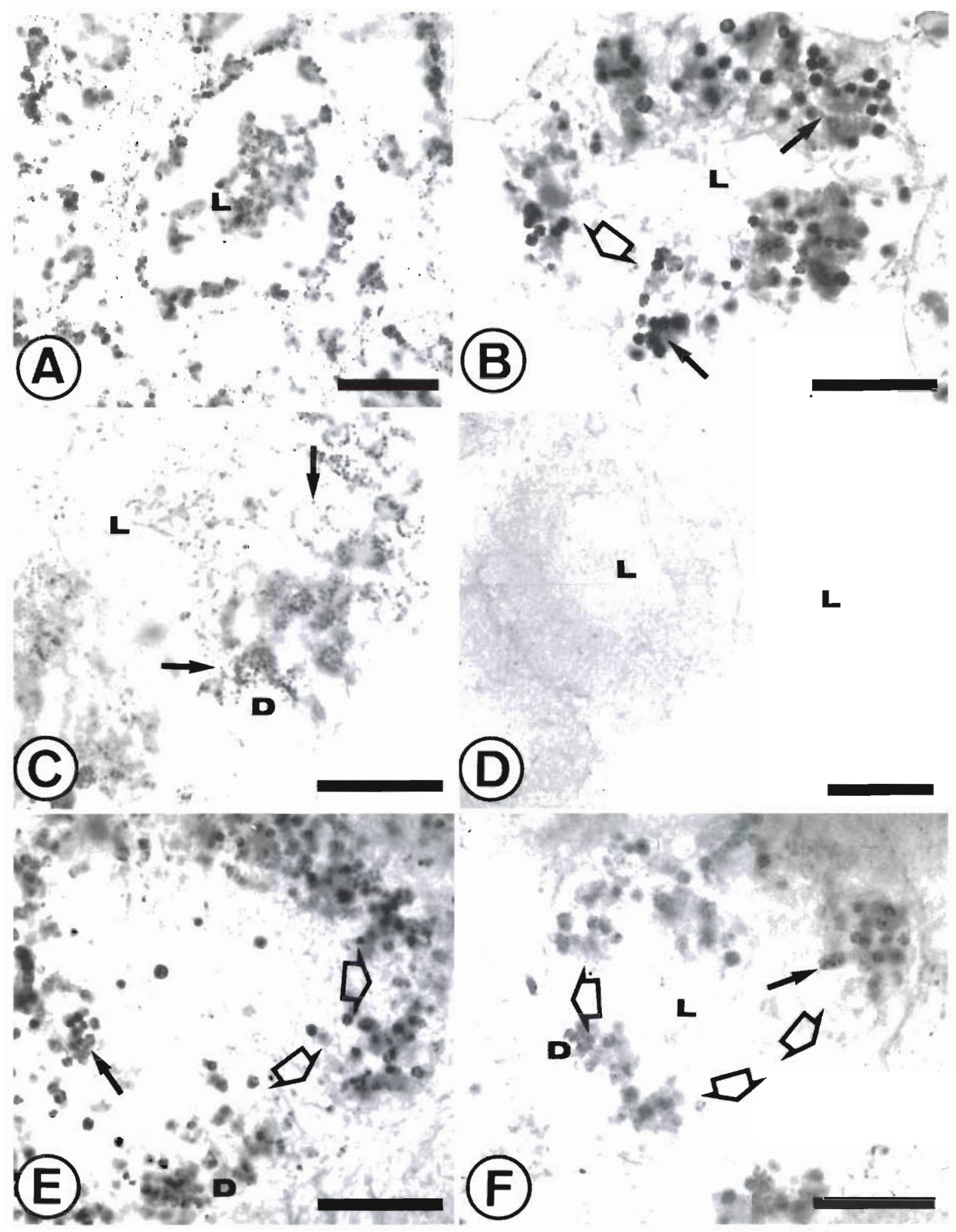

Fig. 2. Mytilus galloprovincialis. Micrographs showing black silver deposits (BSD) in the digestive lysosomes of mussels from (A) Meñakoz, (B) Zierbena, (C) Arrigunaga, (D) Plentzia, (E) Mundaka, (F) Laga. Arrows: BSD in digestive cell lysosomes; D: digestive cells; open arrows: basophilic cells; L: lumen of digestive tubule. Scale bars for (A) and (D) $=40 \mu m$; $5 c a l e$ bars for (B), (C), (E) and $(F)=20 \mu \mathrm{m}$ 


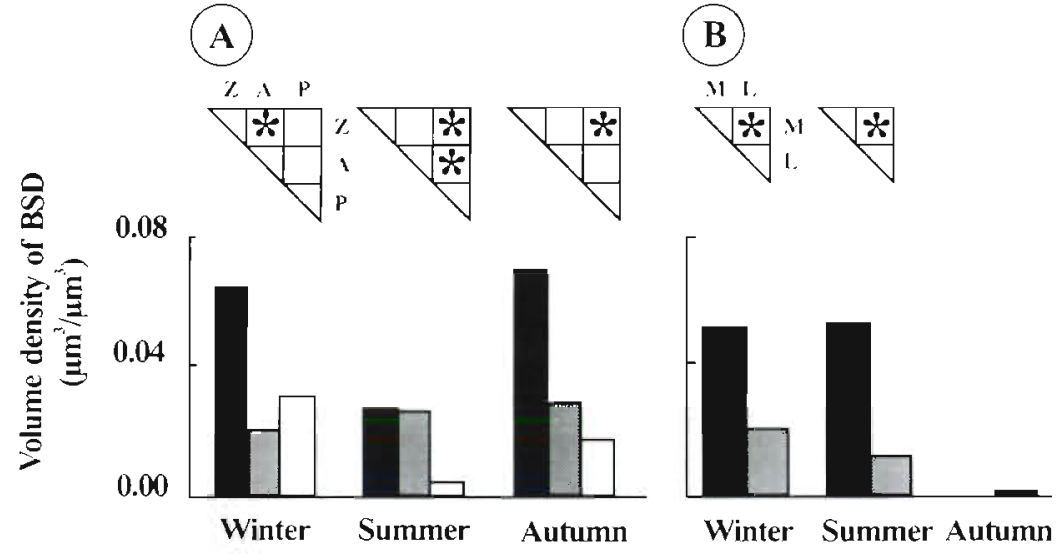

Fig. 3. Mytilus galloprovincialis. Volume density (VD) of black silver deposits (BSD) in the digestive tubules of mussels collected in winter, summer and autumn. (A) Abra (tlack bar, Zierbena; shaded bar, Arrigunaga; open bar, Plentzia. (B) Urdaibai (black bar, Mundaka; shaded bar, Laga). Significant differences between pairs of means are indicated in the upper triangular matrix by asterisks (Duncan's multiple range test, $\mathrm{p}<0.05$ ) $\mathrm{Z}=\mathrm{Z}_{\text {Zerbena; }} \mathrm{A}=\mathrm{Arrigu-}$ naga; $P$ = Plentzia; $M=$ Mundaka; $L=$ Laga
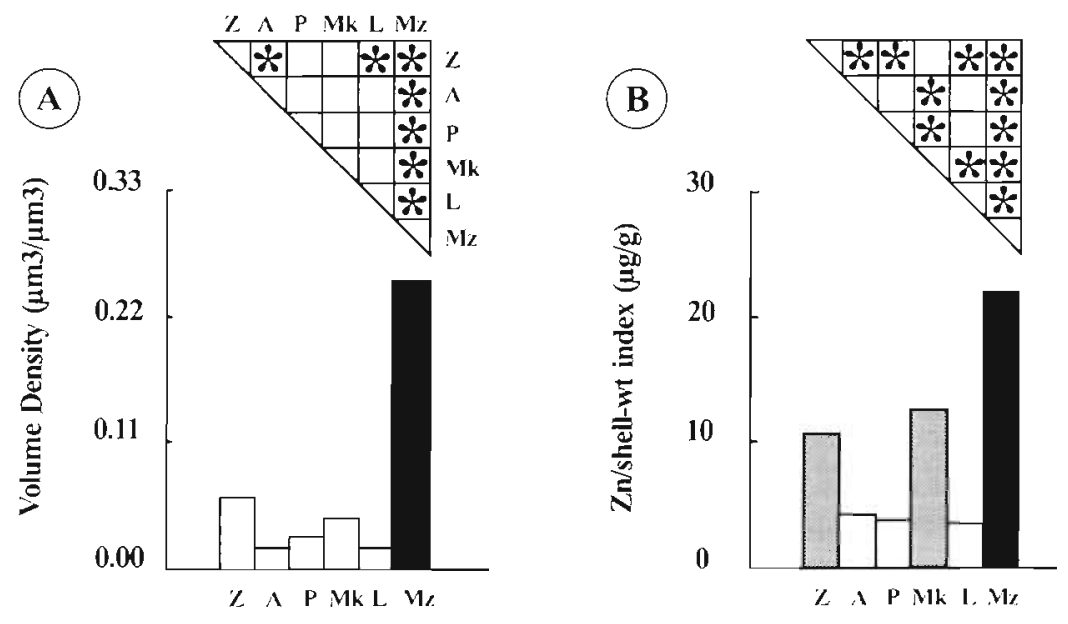

Fig. 4. Mytilus galloprovincialis. (A) Volume density (VD) of black silver deposits (BSD) in the digestive gland of mussels collected in winter. (B) Zn levels in mussels collected in winter ( $\mathrm{Zn} /$ shell-weight indices, $\mu \mathrm{g} \mathrm{Zn} \mathrm{g^{-1 }}$ dry shell weight). Statistics as in Fig. 3. Different grey scales indicate significantly dissimilar subgroups according to Duncan's test. $\mathrm{Z}=$ Zierbena; $\mathrm{A}=$ Arrigunaga; $\mathrm{P}=$ Plentzia; $M k=$ Mundaka; $L=\operatorname{Laga}_{;} \mathrm{Mz}=$ Meñakoz

spectrum was due to the K-pyroantimoniate method used to retain diffusible $\mathrm{Zn}$. The Sb peak shows the presence of $\mathrm{Zn}$. The same analysis (in non-fixed tissues embedded in resin) revealed the presence of different metals in the digestive gland of mussels collected in winter. Iron was the major metal present in digestive lysosomes of musseis from Zierbena (Fig. 5A) and from Arrigunaga (Fig. 5B); $\mathrm{Cu}, \mathrm{Fe}$ and $\mathrm{Zn}$ occurred at low levels in Plentzia (Fig. 5D); $\mathrm{Fe}, \mathrm{Cu}$ and $\mathrm{Ni}$ were detected in Mundaka (Fig. 5E); and the Cu signal was the only significant one in digestive lysosomes of mussels collected from Laga (Fig. 5F).

\section{Correlation between BSD extent in digestive lysosomes and metal/shell-weight indices}

Taking into account the above results on VD of BSD in the digestive cell lysosomes and metal levels quantified by AAS in the digestive gland of mussels, a correlation between VD of $\mathrm{BSD}$ and metal/shell-weight indices was made. The relationship between BSD extent and metal body burdens followed an exponential pattern according to regression analyses. $\mathrm{Zn}$ concentration in soft tissues of mussels from Abra and Urdaibai was the most variable of the metal concentrations recorded. Therefore, the regression coefficient for $\mathrm{Zn}$ concentration was the most significant and explained by itself the regression model (Fig. 6A):

$$
\begin{gathered}
\log (\mathrm{VD} \times 1000)= \\
1.4353+0.93207 \log (\mathrm{Zn}) \\
\left(\mathrm{r}^{2}=0.572 ; \mathrm{n}=16 ; \mathrm{p}<0.05\right)
\end{gathered}
$$

When all the metal body burdens were taken into account, the fit of the regression model was also signizicant (Fig. 6B):

$$
\begin{aligned}
& \log (\mathrm{VD} \times 1000)= \\
& \quad 0.9454+0.8571 \log (\text { Total metal) } \\
& \left(\mathrm{r}^{2}=0.380 ; \mathrm{n}=16 ; \mathrm{p}<0.05\right) .
\end{aligned}
$$

\section{DISCUSSION}

The quantification of BSD in digestive lysosomes of mussels by means of automated image analysis of VD showed that lysosomes of missels from Meñakoz exhibited a higher BSD extent than those collected in the same season in the Abra and Urdaibai estuaries. In agreement with this finding. $Z n$ was proved to be present in this cellular compartment by X-ray microprobe analysis. It has been reported that the levels of $\mathrm{Zn}$ were highly variable even among mussels from the same site (Lobel \& Marshall 1988). However, the $\mathrm{VD}$ of BSD in digestive lysosomes of mussels collected in the field and quantified by automated image analysis is not so variable between mussels and may reflect genuine differences in $\mathrm{Zn}$ bioavailability, which is the most variable of the metals recorded (Soto et al. 1995). 


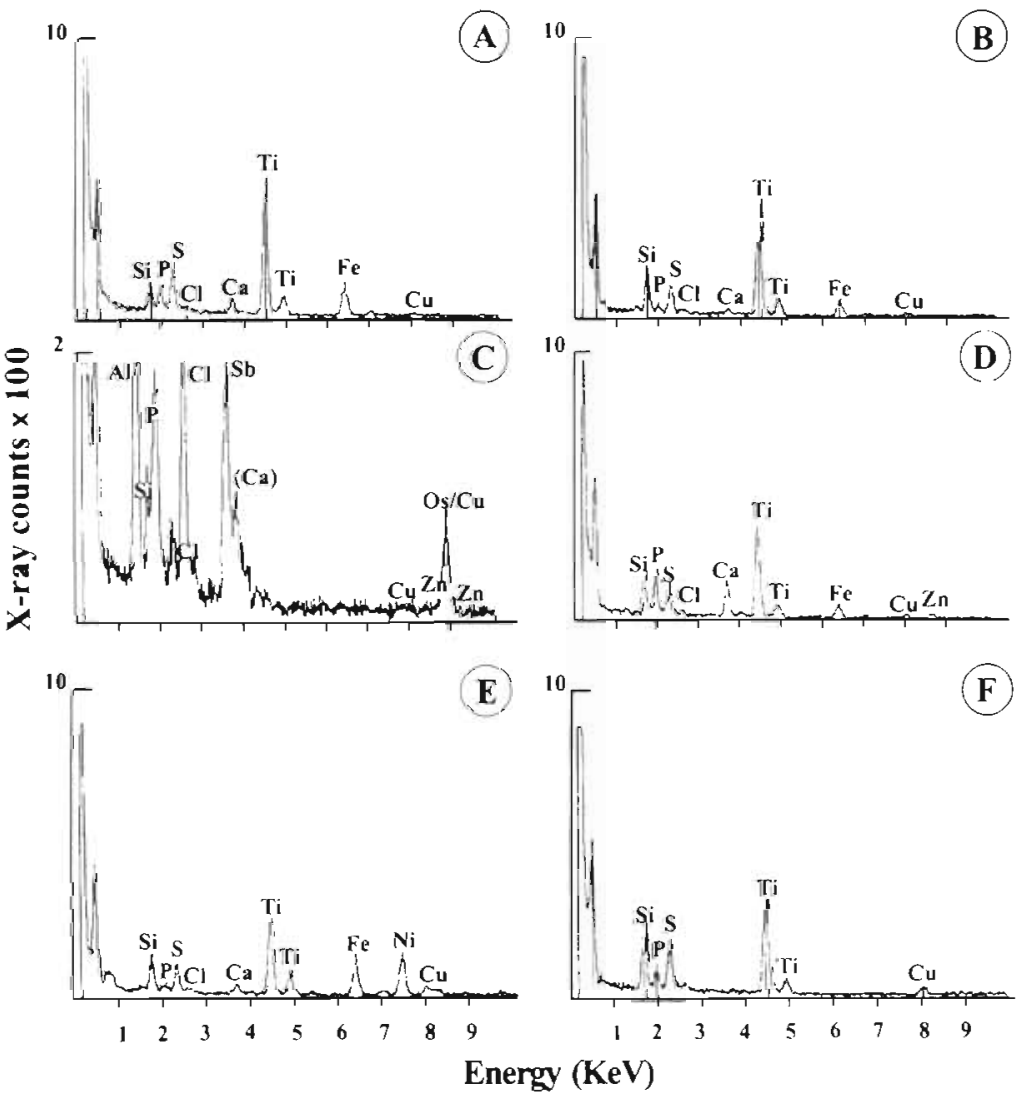

Fig. 5. EDS spectra derived from microanalysis of digestive lysosomes in the digestive gland of Mytilus galloprovincialis collected in the Abra Estuary $(A-D)$ and in the Urdaibai Estuary (E-F). (A) Zierbena, (B) Arrigunaga, (C) Meñakoz, (D) Plentzia, (E) Mundaka, (F) Laga. The peaks for titanium, Ti, $(\mathrm{A}, \mathrm{B}, \mathrm{D}, \mathrm{E}, \mathrm{F})$ and aluminium, $\mathrm{Al},(\mathrm{C})$ correspond to the grid used. The time for $\mathrm{X}$-ray counts was the one needed to obtain total counts ranging between 60000 and 70000 except in (C) (50000 total counts)
The Abra Estuary has been previously considered to be a metal-polluted site (Azkona et al. 1984, Swindlehurst \& Johnston 1991). However, Soto et al. (1995) concluded that metal levels were not very high but, nevertheless, differences in body burdens of bioavailable metals between seasons and sampling sites were found when applying metal/ shell-weight indices. The metal/shellweight indices appear to remain unchanged by seasonal factors other than metal bioavailability, indicating the existence of seasonal trends in metal/ shell-weight indices (Soto et al. 1995). The same seasonal trend was observed in the values of VD of BSD in digestive cell lysosomes of mussels from the same sites in winter, summer and autumn. In relation to spatial differences, the western side of the estuary exhibited higher metal bioavailability than the eastern side, whilst Plentzia, away from the influence of Abra Estuary, was considered as a reference site. Accordingly, mussels from Zierbena showed the highest $V D$ of BSD in digestive lysosomes, the lowest values being found in mussels from Plentzia. These high VD of BSD in mussels from Zierbena was probably due to the high amount of Fe present in soft tissues (determined by AAS $_{i}$ Soto et al. 1995) and in diges-
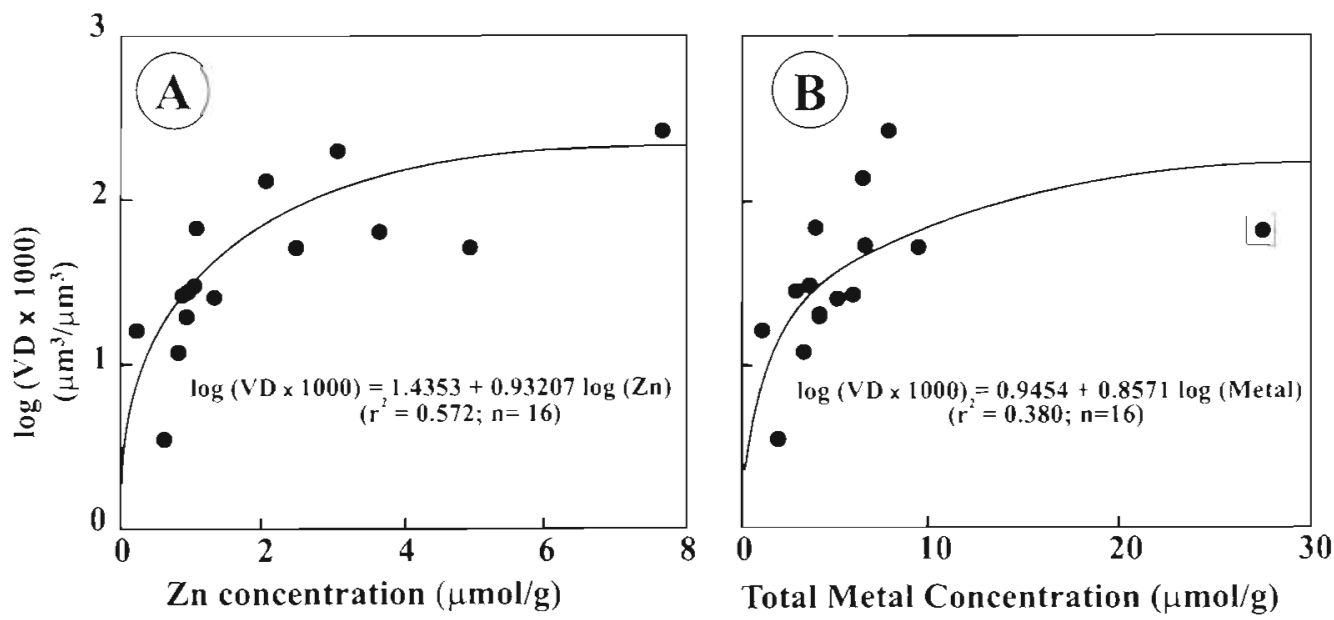

Fig. 6. (A) Correlation between autometallographical deposits $\left[\mu \mathrm{m}^{3} / \mu \mathrm{m}^{3}, \log (\mathrm{VD} \times 1000)\right]$ and $\mathrm{Zn} /$ shell-weight index $\left(\mu \mathrm{mol} \mathrm{Zn} \mathrm{g}^{-1}\right.$ dry shell weight) in mussels from all the sampling sites in winter, summer and autumn. (B) Correlation between autometallographical deposits $\left[\mathrm{mm}^{3} / \mu \mathrm{m}^{3}, \log (\mathrm{VD} \times 1000)\right]$ and total metal concentrations ( $\mu \mathrm{mol}$ total metal concentration $\mathrm{g}^{-1}$ dry shell weight) in mussels from all the sampling sites in winter, summer and autumn. The point inside a square represents mussels from Zierbena showing a high bioavailability for Fe 
tive lysosomes (determined by X-ray microanalysis; present work). Mussels from Arrigunaga showed an intermediate metal bioavailability, in agreement with intermediate values of $\mathrm{VD}$ of BSD in digestive lysosomes. According to $X$-ray microprobe analysis, the major metal in the digestive tissue of these mussels was Ni. Consequently, the VD of BSD in digestive lysosomes of these mussels reflects changes in the metal content of the digestive gland of mussels that concomitantly reflects changes in the fraction of bioavailable metals in seawater (including $\mathrm{Fe}, \mathrm{Ni}, \mathrm{Cu}$ and $\mathrm{Zn}$ as shown by $\mathrm{X}$-ray microanalysis) during

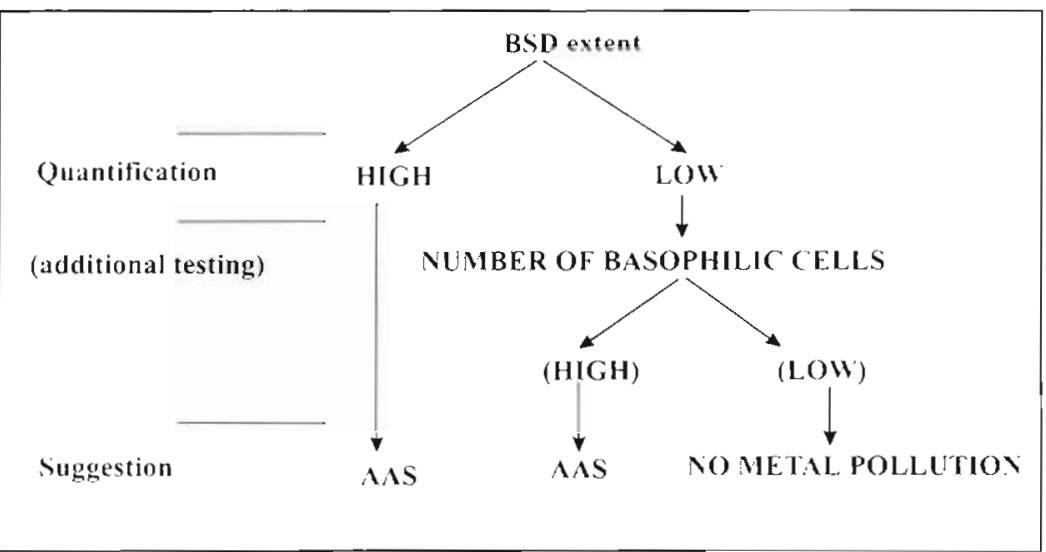

Fig. 7. Proposed protocol to be applied in 'mussel-watch' biological monitoring programmes the sampling period and among sites.

On. the other hand, the quantitative method applied herein could be considered a very sensitive tool for detecting slight differences in metal bioavailability when chemical analyses are not sufficiently sensitive. Accordingly, in Urdaibai, an estuary without differences in metal bioavailability (Soto et al. 1996c), the sensitivity of the autometallographical approach is higher than that of chemical analyses for detecting spatial differences in metal bioavailability. In this regard, chemical analyses revealed $\mathrm{Fe}, \mathrm{Ni}$ and $\mathrm{Cu}$ in the digestive gland of mussels from Mundaka (the presence of these metals in digestive cell lysosomes was also confirmed by X-ray microanalysis), but significant differences in metal/shell-weight indices were not found when comparing with mussels from Laga. However, autometallography did reflect significant differences in metal bioavailability in terms of VD of BSD in digestive lysosomes, the highest levels of metals being in Mundaka.

The extent of BSD in digestive cell lysosomes and the extent of BSD in the basal lamina of digestive tubules of winkles have been previously related to $\mathrm{Cu}$ and $\mathrm{Zn}$ concentrations, respectively, in the digestive gland/ gonad complex (Soto et al. in press a). In the case of musseis, the basal lamina diu nol exhibit BSD (Soto et al. 1996b), but the extent of BSD in digestive lysosomes seems to be a good index for detecting changes in metal levels in the digestive gland (Soto \& Marigómez in press). However, under these laboratory conditions, the extent of BSD revealed by autometallography reaches a saturation threshold when high metal concentrations are present in the tissue, beyond which further increases cannot be detected (Soto \& Marigómez in press, Soto et al. in press a). In the present study, a significant correlation was found between the $\mathrm{Zn} / \mathrm{shell}$-weight index and the VD of BSD in digestive lysosomes of mussels from different sites on the coast showing high variability of $\mathrm{Zn}$ concentrations in soft tissues. Additionally, when total metal concentrations $\left(\mu \mathrm{mol} \mathrm{\textrm { } ^ { - 1 } )}\right.$ measured by AAS were related to VD of BSD in digestive lysosomes, a similar regression model was obtained.

In conclusion, bioavailable metals can be estimated by analysing the VD of BSD in tissue sections of sentinel mussels. Autometallography exhibits a great sensitivity in localising metals, but according to our regression models, it seems that a saturation occurs when elevated levels of metals are present in the tissues. For this reason, this may a very useful tool allowing workers to dispense with chemical analysis of biological samples - i.e. molluscs - when the extent of BSD, revealing small traces of metals, is low in the tissues. However, taking into account previous results, the amount of basophilic cells present in digestive tissue has to be checked before any feasible conclusion can be reached (Fig. 7). Thus, presently, this quantitative index can be used in biological monitoring programmes in combination with chemical analyses since it provides a quick and cost-effective alternative to routine chemical analyses.

Acknowledgements The authors are greatly indebted to $\mathrm{Mr}$ I. Quincoces, Mr X. Lekube, Mr A. Antón, Mrs l. Romano and Mrs M. J. Bidaurrazaga for their excellent technical support. The facilities for X-ray mucroprobe analysis provided by the Scientific \& Technical Services of the University of Barcelona are also acknowledged. This work was funded by the Basque Government (RBU/GV9044) and the Ministry of Education and Science (NAT90-0280 and Research Fellowshup to M.S.).

\section{LITERATURE CITED}

Azkona A, Jenkins SH, Roberts HMG (1984) Sources of pollution of the river Nervion, Spain - a case study. Wat ScI Tech 16:95-125

Cajaraville MP, Marigómez JA, Angulo E (1991) Automated 
measurement of lysosomal structure alterations in oocytes of mussels exposed to petroleum hydrocarbons. Arch Environ Contam Toxicol 21:395-400

Chandler JA (1977) X-ray microanalysis in the electron microscope. In: Glauert AM (ed) Practical methods in electron microscopy. North-Holland Publ Co, Amsterdam

Compère P, Morgan JA, Goffinet G (1993) Ultrastructural location of calcium and magnesium during mineralisation of the cuticle of the shore crab, as determined by the Kpyroantimoniate method and X-ray microanalysis. Cell Tiss Res 274:567-577

Danscher G (1981) Histochemical demonstration of heavy metals. A revised version of the sulphide silver method suitable for both light and electron microscopy. Histochemistry 71:1-16

Danscher G (1984) Autometallography. A new technique for light and electron microscopic visualization of metals in biological tissues (gold, silver, metal sulphides and metal selenides). Histochemistry 81:331-335

Danscher G (1991) Histochemical tracing of zinc, mercury, silver and gold. In: Graumann W, Drukker J (eds) Histoand cytochemistry as a tool in environmental toxicology. Progress in histo- and cytochemistry. Fischer Verlag, Stuttgart, p 273-285

Danscher G, Montagnese C (1994) Autometallographical localization of synaptic vesicular zinc and lysosomal gold, silver and mercury. J Histotechnol 17:15-22

Fischer H (1984) Cadmium body burden/shell weight of mussels: a precise index for environmental monitoring. Comm Meet Int Coun Explor Sea CM-ICES/E 41:1 19

Fischer $\mathrm{H}$ (1986) Influence of temperature, salinity and oxygen on the cadmium balance of mussel Mytilus edulis. Mar Ecol Prog Ser 32:265-278

Fischer $H$ (1988) Mytilus edulis as a quantitative indicator of dissolved Cd. Final study and synthesis. Mar Ecol Prog Ser 48:163-174

Glauert AM (1986) Fixation, dehydration and embedding of biological specimens. Elsevier, North Holland Inc, New York

Hacker GW, Grimelius L, Danscher G, Bernatzky G, Muss W, Adam H, Turner J (1988) Silver acetate autometallography: an alternative enhancement technique for ummunogold-silver staining (IGSS) and silver amplification of gold, silver, mercury and zinc in tissues. J Histotechnol 11:213-221

Hayat MA (1993) Stains and cytochemical methods. Elsevier, New York

Hemelraad J, Herwig HJ (1988) Cadmium kinetics in freshwater clams. IV. Histochemical localization of cadmium in Anodonta cygnea and Anodonta anatina exposed to cadmium chloride. Arch Environ Contam Toxicol 17:337-343

Herwig HJ, Brands F, Kruitwagen E, Zandee DI (1989) Bioaccumulation and histochemical localization of cadmium in Dreissena polymorpha exposed to cadmium chloride. Aquat Toxicol 15:269-286

Lobel PB, Marshall HD (1988) A unique low molecular weight zinc-binding ligand in the kidney cytosol of the mussel Mytilus edulis, and its relationship to the inherent variability of zinc accumulation in this organism. Mar Biol 99:101-105

Lowe DM, Moore MN, Clarcke KR (1981) Effects of oil on digestive cells in mussels: quantitative alterations in cellular and lysosomal structure. Aquat Toxicol 8:265-272

Marigómez I, Ireland MP (1989) Accumulation, distribution and loss of cadmium in the marine prosobranch Littorina littorea (L.). Sci Tot Environ 78:1-12

Marigómez I, lreland MP (1990) A laboratory study of cad- mium exposure in Littorina littorea in relation to environmental cadmium and exposure time. Sci Tot Environ 90: $75-87$

Marigómez I, Ireland MP, Angulo E (1990) Correlation of cadmium shell-weight index with environmental stress indicators at the cellular and organismic levels in Littorina littorea. Mar Ecol Prog Ser 67:171-176

Marigómez I, Soto M, Cajaraville MP (1995) Cell and tissue models for the study of the cellular metabolism of metals. In: Cajaraville MP (ed) Cell biology in environmental toxicology. University of the Basque Country Press Service, Bilbo, p 89-134

Marigómez I, Soto M, Etxeberria M, Angulo E (1992) Selection of mussels watch specimens based on metal/shell-wt indices and on organismic and cellular condition indices. 2nd European Conference on Ecotoxicology, Amsterdam. RIVM/SECOTOX, Amsterdam, p 2-11 (Abstract)

Martoja R, Martoja-Pierson M (1970) Técnicas de histologia animal. Toray Masson SA, Barcelona

Morgan AJ (1985) X-ray microanalysis in electron microscopy for biologists. Oxford Univ Press, New York

Pearse AGE (1980) Histochemistry. Theoretical and applied, Vol 1, Preparative and optical technology, 4th edn. Churchill Livingstone, Edinburgh

Phillips DJH (1976) The common mussel Mytilus edulis as an indicator of pollution by zinc, cadmium, lead and copper. I. Effects of environmental variables on uptake of metals. Mar Biol 38:56-59

Phillips DJH (1980) Quantitative aquatic biological indicators. Applied Science, Barking

Rainbow PS (1993) The significance of trace metal concentrations in marine invertebrates. In: Dallinger $R$, Rainbow PS (eds) Ecotoxicology of metals in invertebrates. Lewis Publ, Boca Raton, p 3-23

Regoli F, Orlando E (1993) Mytilus galloprovincialis as a bioindicator of lead pollution: biological variables and cellular responses. Sci Tot Environ Suppl 1283-1292

Soto M (1995) Simultaneous quantification of bioavailable metals in molluscs by means of cellular and tissue analysis. Implications for monitoring metal pollution in water quality assessment. PhD thesis, University of the Basque Country, Bilbo

Soto M. Cajaraville MP, Angulo E, Marigómez I (1996a) Autometallographic localization of protein-bound copper and zinc in the common winkle, Littorina littorea: a light microscopical study. Histochem J 28:1-13

Soto M. Cajaraville MP, Marigómez I (1996b) Tissue and cell distribution of copper, zinc and cadmium in the mussel Mytilus galloprovincialis determined by autometallography. Tiss Cell 28:557-568

Soto M, Kortabitarte M, Marigómez I (1995) Bioavailable heavy metals in estuarine waters as assessed by metal/shellweight indices in sentinel mussels Mytilus galloprovincialis. Mar Ecol Prog Ser 125:127-136

Soto M, Kortabitarte M. Marigómez l (1996c) Bioavailable heavy metals in the Urdaibai estuary (Biscay Coast) as assessed by metal/shell-weight indices in Mytilus galloprovincialis. Pol J Environ Stud 5:59-66

Soto M, Marigómez I (1995) Techniques for the study of metals in cell biology. In: Cajaraville MP (ed) Cell biology in environmental toxicology. University of the Basque Country Press Service, Bilbo, p 59-88

Soto M. Marigómez I (in press) BSD extent, and index for metal pollution screening based on the metal content within digestive cell lysosomes of mussels as determined by autometallography. Ecotox Environ Saf

Soto M, Quincoces I, Lekube X, Marigómez I (in press a) 
Autometallographied metal content in digestive cells of winkles: a cost-effective screenıng tool to monitor $\mathrm{Cu}$ and Zn pollution. Aquat Toxicol

Soto M, Quincoces I, Marigómez I (in press b) Improved autometallographical procedure for the localisation of metal traces in molluscan tissues at the light-microscope. $J$ Histotechnol

Swindlehurst RJ, Johnston PA (1991) Grave contaminación ambiental por metales pesados y HAPs en Bilbao, Espana. Technical Report Greenpeace, Queen Mary and Westfield

This article was submitted to the editor
College, University of London

Theede H, Soria SPC (1990) Contrbution to improving assessment of heavy metal pollution in coastal waters. In: Yap HT, Behle-Carbonell M, Gernet ED (eds) Oceanography and marine pollution: an Asian-EC perspective. Marine Science Institute, Manila, p 277-291

Widdows J, Donkin P (1992) Mussels and environmental physiological aspects. In: Gosling $E$ (ed) The mussel Mytilus: ecology, physiology, genetics and culture. Elsevier, Amsterdam, p 383-424

Manuscript received: February 10, 1997 Revised version accepted: June 25, 1997 